\title{
Power-Sharing Between NS and NNS Teachers: Linguistically Powerful AETs vs. Culturally Powerful JTEs
}

\section{Kyoko Miyazato \\ Hakuoh University}

This study investigates team teaching (TT) relationships between AETs (Assistant English Teachers) and JTEs (Japanese Teachers of English) focusing on power-sharing in Japanese high schools. From September 2003 to March 2004, a naturalistic case study was conducted with two TT pairs during bimonthly visits through class observation and individual interviews. Supplementary data were also collected by interviewing students. Research results revealed that the AETs were given full autonomy because of their language power, which caused the JTEs to become peripheral participants. This resulted in the JTEs' dissatisfaction with their TT performance. Furthermore, the JTEs' identity influenced by language power inequality was deeply involved in their peripheral participation, which was supported by the belief in the native speaker fallacy, the idea that NSs are automatically the best teachers of the language (Phillipson, 1992), at the educational, societal, and individual levels.

本研究は、日本の高校における日本人英語教師 (JTE) と英語指導助手 (AET) のティームティ 一チング(TT)における関係について、教師間の力配分に焦点を置き、調査することを目的とす る。2003年9月から2004年 3 月まで、2組のTTペアを対象としたケーススタディーが実施され、月 2 回の訪問時に授業参観とTTペアへの個別インタビューが行われた。補足のデータとして、生 徒へのインタビューも併せて行われた。その結果、AETは高い英語力ゆえに授業の自治権を完 全に与えられている一方、JTEのTTへの参加は消極的となり、結果としてJTEはTTの出来栄え に対して不満を感じていたことが判明した。また、語学力の不均衡によって影響を受けたJTEの アイデンティティーが、JTEの消極的TT参加と密接に関わっており、このことは、教育界、社会、 個人レベルに見られるネイティブスピーカー信仰(ネイティブスピーカーであれば自動的によい 語学教師であるとする考え)が一因であることが示唆された。

Keywords: NS-NNS, the JET Program, team teaching, power

JALT Journal, Vol. 31, No. 1, May, 2009 
$\mathrm{S}$ ince the inception of the JET (Japan Exchange and Teaching) Program in 1987, team teaching (TT) involving a Japanese teacher of English (JTE) and an assistant English teacher (AET) has been a distinctive feature of public school education in Japan. Yet team teaching has been dogged by controversy mainly because of team teachers' relationships (McConnell, 2000; Mahoney, 2004; Tajino \& Walker, 1998). Naturally, giving up autonomy, one of the basic needs that bring about intrinsically motivated teacher behavior (Deci \& Ryan, 1985), must be enormously difficult for teachers who are used to their status as the sole authority in the classroom. Moreover, team teachers in Japan differ from each other in multiple waysin terms of professional status (teacher-in-charge versus assistant), linguistic proficiency (nonnative versus native speaker) and cultural background (cultural native versus cultural nonnative). These differences are likely to involve power issues. The main purpose of this study, therefore, is to explore TT relationships between JTEs and AETs focusing on nonnative speaker (NNS)-native speaker (NS) power/role-sharing in the classroom.

\section{Literature Review}

\section{What is the JET Program?}

According to a handbook for JET participants called The JET Programme 2003-2004, issued by the Council of Local Authorities for International Relations (CLAIR, 2003), this is one of the world's largest international exchange programs. The program description is as follows:

The JET Programme enables local authorities (prefectures, designated cities and other municipalities) to employ foreign youth for the purpose of foreign language education as well as promoting international exchange at the community level. By teaching foreign languages at schools nationwide and assisting with international exchange activities organized by local authorities, participants engage in international exchange on a variety of levels with local residents. In this way, the Programme is expected to increase cross-cultural understanding as well as contribute to internationalisation efforts in Japan. (p. 2)

The JET Program has been gradually expanding every year since its inception in 1987. The number of NS participants in 1987 was 848 from four countries, but by 2003 it had reached 6,226 from 40 countries (CLAIR, 
2003). As of 1999 , there were more than 20,000 alumni of this program (McConnell, 2000).

Jobs for participants in the JET Program are divided into three categories: Coordinators of International Relations (CIRs), who are engaged in international activities in prefectural or municipal offices; Sports Exchange Advisors (SEAs), who are placed with local authorities engaged in sports-related activities; and Assistant Language Teachers (ALTs), who team-teach foreign language classes such as English, French, German, Chinese, and Korean in public elementary, junior, and secondary schools (CLAIR, 2003). However, McConnell (2000) has pointed out that more than 90\% of all JET Program participants are AETs, and, therefore, that their primary duty is to teach EFL with JTEs in public school settings.

\section{Historical Background of the JET Program}

Compared to the previous language programs such as MEF (Mombusho English Fellow) and BETS (British English Teacher Scheme), which were organized solely by the then Ministry of Education in order to improve EFL education in Japan, the JET Program was originally founded for political reasons. McConnell (2000, p. 1) explained that the JET Program, a $\$ 500$ million "top-down" project, was a "gift" presented at the "Ron-Yasu" (U.S. President Ronald Reagan and Japanese Prime Minister Yasuhiro Nakasone's) summit in 1986 during Japan's economic boom. In the mid-1980s, Japan needed to deal with the economic conflicts it was having with its business partners, especially U.S.-Japan trade friction. Lincicome (1993, p. 127) stated that Japan's Kokusaika was "an action against the criticism of Japan's economic self-centeredness and cultural insularity." Thus, internationalization emerged as a political means of enhancing an understanding of Japan and softening economic criticism against it. Seen in this light, the Japanese government established the JET Program as a means of realizing Kokusaika and has, from its inception, hired foreign youth-mostly from Japan's main trading partner, the United States-as JET participants with the expectation that they would enjoy working in Japan and then take those positive experiences with them on completing their assignments. The experiences of these individuals are therefore supposed to have a positive effect on Japan-U.S. economic relationships overall (McConnell, 2000).

As an adjunct to Japan's internationalization, emphasizing the necessity of communicative competence in EFL education was regarded as an important task (Wada, 1994). To implement this task, EFL educational policy has shifted from form-focused instruction based mainly on translating English 
texts (yakudoku) to Communicative Language Teaching, or CLT (Gorsuch, 1999). For example, in the late 1980s, the Ministry of Education established oral communication (OC) courses in secondary education to develop students' listening and speaking skills. The JET Program was established to promote such changes-English NSs were brought in en masse to assist JTEs by providing authentic NS models and opportunities for communication (Samimy \& Kobayashi, 2004).

\section{Team Teaching Between AETs and JTEs}

Brumby and Wada (1990) defined TT under the JET Program as follows:

Team teaching is a concerted endeavour made jointly by the Japanese teacher of English (JTE) and the assistant English teacher (AET) in an English language classroom in which the students, the JTE and the AET are engaged in communicative activities. (Brumby \& Wada 1990, Introduction, no page number)

Brumby and Wada specified various benefits of TT for students: providing authentic interaction with AETs for learning how to communicate in English; offering a model of interaction with an NS through in-class English conversation between JTEs and AETs, and promoting cross-cultural awareness through the differing viewpoints of the two teachers.

Presumably, TT is beneficial for teachers as well, especially JTEs. That is, another purpose of TT in the JET Program was to create on-the-job training opportunities in order to improve JTEs' English communicative abilities by having them share classes with an NS on a regular basis (Gorsuch, 2002; McConnell, 2000; Wada, 1996; Wada \& Cominos, 1994). This was ultimately expected to raise JTEs' awareness of English as a communicative medium and promote CLT in the classroom. Gorsuch reported that AETs have encouraged professional and personal growth in JTEs by exposing them to new and different teaching styles and increasing their communicative English ability.

\section{Present Problems Regarding TT Relationships}

TT in the JET Program, however, faces tremendous difficulties and conflict. Tajino and Walker (1998) explained that many of the problems are centered on the relationship between the JTE and the AET. McConnell (2000) also pointed out various power imbalances between the two parties-for example, JTEs' deficiency in English conversational ability, Japanese students' 
and society's admiration of NSs, AETs' difficulty in understanding classroom culture, and AETs' exclusion from major decision-making in teaching EFL in Japanese schools.

In implementing the JET program, its designers initially assumed that problems arising from responsibility-sharing would be solved by professional status differences-between the JTE as a qualified and experienced teacher-in-charge, versus the AET as an uncertified assistant, typically with little formal training and teaching experience. However, this planned status difference has caused confusion in the classroom. According to Resource Materials \& Teaching Handbook 2000 (CLAIR, 2000), a major TT-related publication for AETs, for example, the importance of AETs' roles as language consultants and cultural informants is emphasized. However, some AETs were originally used by JTEs as so-called "living tape recorders," based on the assumption that the AETs were only assistants (Kumabe, 1996). Consequently, the AETs' role as an assistant has been questioned and criticized. The criticism indicates that AETs should take a more active role if CLT is to be realized in Japanese EFL education.

In recent years, however, JTEs have tended to take a more passive role, acting as "interpreters" (Iwamoto, 1999; Mahoney, 2004; Tajino \& Walker, 1998), which has made team-taught classes more AET-centered. Some JTEs defer to AETs, who are after all NSs of the target language, by surrendering initiative and leadership, owing to feelings of inferiority vis-à-vis their English abilities (Murai, 2004; Tajino \& Walker, 1998). Students' perceptions of the AET as the main teacher have also encouraged JTEs to take a less conspicuous role as assistants to the AETs (Iwamoto, 1999).

Another problem with respect to TT involves its legitimacy in Japanese EFL education. Japanese students' primary goal is still to pass entrance examinations wherein English grammar and reading are heavily emphasized (Gorsuch, 1999; McConnell, 2000; Samimy \& Kobayashi, 2004; Voci-Reed, 1994). Although TT in the JET Program was established to improve Japanese EFL learners' communicative competence, which was regarded as important for Japan's internationalization, Wada $(1996$, p. 8) mentioned that TT classes have been displaced from the mainstream goals of English education in Japan under the pressure of grammar-emphasized entrance examinations. In other words, under this pressure, most English classes are conducted in Japanese by JTEs in order to transmit such information effectively. As a result, AETs are not allocated to teach other English classes but only OC courses (Gorsuch, 2002: Mahoney, 2004). Reflecting the lack of consistency of EFL education policy and its implementation, the Ministry of Educa- 
tion, Culture, Sports, Science and Technology (MEXT) finally announced in March 2003 that a listening test would be included, beginning in 2006, in the English section of the University Center Examination (Center Nyuushi), the preliminary entrance examination used mainly for public universities. However, only a few private universities have a listening component in their examinations. Thus, the discrepancy between the government's directive, aimed at promoting internationalization through CLT, and local priorities with respect to entrance examination preparation has contributed to a loss of legitimacy for TT (Samimy \& Kobayashi, 2004).

\section{Reported Difficulties of AETs: Lack of Political Power and Local Language/Cultural Skills}

Researchers have pointed out that AETs lack political power as short-term assistants in Japanese schools (McConnell, 2000; Mahoney, 2004; Voci-Reed, 1994). For instance, AETs' appointments are limited in terms of age (they must be less than 35 years old) and length of employment (a maximum of five years). ${ }^{1}$ In addition, AETs are not allowed to evaluate or give final grades to students because of their official status as assistants. Thus, AETs have little influence on and involvement in decision making concerning the overall direction of English teaching (McConnell, 2000) and this leads to feelings of frustration and disappointment (Voci-Reed, 1994).

Understanding the local culture of Japanese high schools and the Japanese language seem to present additional difficulties. For instance, researchers have reported high levels of anxiety among Japanese EFL learners in NSs' English-only classes due to the learners' lack of exposure to spoken English (Ellis, 1993), as well as such learners' psychological distance from NSs due to cultural and linguistic differences (Miyazato, 2003). Conversely, McConnell (2000) described AETs' frustration toward one particular aspect of Japanese classroom culture-the lack of responsiveness or shyness of Japanese students. In addition, the dominant Japanese teaching style, which, despite the CLT reforms mandated by the Ministry of Education (see above), still focuses on form rather than meaning and therefore interferes with the implementation of CLT, may prove frustrating to AETs (Browne \& Evans, 1994; Ellis, 1996). Thus, both AETs' cultural values and teaching methods may be ineffective because of local cultural realities (Holliday, 1994; Liu, 1999).

\section{Reported Difficulties of JTEs: English Language Deficiency and Native Speaker Fallacy ${ }^{2}$}

Some JTEs defer to AETs, who are after all NSs of the target language, because they feel they have inferior English abilities (Kamhi-Stein, 1999; 
McConnell, 2000; Tajino \& Walker, 1998). According to the newspaper report ("Sensei ga chikara busokuja," 2005) concerning a survey conducted by MEXT, only $8.3 \%$ of JTEs in junior high schools and only $16.3 \%$ of JTEs in senior high school have a TOEIC score of 730 (equivalent to TOEFL score 550 ) or more. ${ }^{3}$ It also reported that only $3.9 \%$ of JTEs in public junior high schools and $1.1 \%$ of JTEs in public senior high schools conducted English classes mostly in English. These results reveal the reality of JTEs' English language deficiency and their corresponding lack of confidence in conducting classes in English.

In addition, Japanese people's sociocultural image of English and its NSs appears to be deeply involved in JTEs' deference to AETs. The authenticity of NSs' English and an elite or "exotic" image of NS teachers have been noted by Japanese EFL learners (Miyazato, 2003; Sugino, 2002). This attitude is reported to be reinforced by learners' parents, who themselves have doubts about JTEs' English skills (Takada, 2000).

Likewise, various researchers have reported that Japanese people still generally support the supremacy of NS English (Butler, 2005; Kubota, 1998; Samimy \& Kobayashi, 2004). The Japanese have historically adopted English and its cultures as a symbol of Westernization, and admire Anglo speakers of English due to their prestigious image (Kubota, 1998; Suzuki, 1999; Tsuda, 1997). Kubota has further argued that Japanese perceptions of the NNS of English as inferior to the Anglo speaker of English make the Japanese wish to identify themselves with white Westerners by learning English.

\section{Power/Responsibility Sharing Between JTEs and AETs}

AETs' lower status as assistants was intentionally created in order to equalize the power balance between NSs and NNSs in TT settings (Fujikake, 1996). In addition to the tendency for TT to lead to resistance on the part of JTEs because of their loss of full autonomy in the classroom (McConnell, 2000), JTEs were more hesitant to team teach with AETs at the outset of the JET Program due to JTEs' perceived English communicative deficiency (Ogawa, 1998). That is, it was speculated that AETs would be enormously powerful owing to their language superiority, which would surpass any other advantages that JTEs might have. In fact, AETs' employment conditions (an age limit of 35 and a 5-year employment limit) could ensure that AETs remain politically powerless. In fact, most AETs are recent college graduates in their early 20s (CLAIR, 1992) with little or no formal training or experience in teaching EFL or even teaching itself (Tajino \& Tajino, 2000); prior living experience in Japan was limited to a 3-year maximum. In other words, 
bringing in young untrained native speakers as assistants was considered less threatening to JTEs, and as such was thought to create more balanced power-sharing in the classroom. Wada (1994) actually revealed that AETs with an equal role to JTEs acted as innovators, which could be perceived by JTEs as creating confusion and friction. Thus, deliberately putting AETs in a lower-status position in the classroom may have been necessary for persuading JTEs, who often have an inferiority complex in regard to their English language abilities, to accept TT.

In sum, power imbalances between JTEs and AETs appear to be caused by the different capabilities of the two parties: AETs with language superiority (language power) and JTEs with political power in the local society and a better understanding of the language learning situation and the learners (political/cultural power). Therefore, examining how the differing power structure in TT pairs influences their role-sharing is a key to understanding TT relationships between AETs and JTEs.

\section{Method}

\section{Participants}

The participants in this study were two teaching pairs (two paired JTEs and AETs) who were involved in TT in the JET Program at different public senior high schools in the North Kanto district. Team 1 worked for a boys' high school in a small city about $100 \mathrm{~km}$ north of Tokyo (School 1). The observed class was a required Oral Communication I (OC I) course containing 40 first-year students. JTE 1, a Japanese male in his mid-40s, had studied in the U.S. during his senior year at university. Based on my observations, JTE 1's English oral/aural skills were high. He had passed the highest level of the STEP [Eiken] Test, and his TOEFL score from 20 years previously had been over 600. AET 1, a white American male in his mid-30s, had 4 years of English-teaching experience at the high-school level in the U.S. and was in his 2 nd year as an AET. His main stated reasons for applying to the JET Program were his interest in different cultures and the relatively high salary.

Team 2 worked for a relatively new co-educational high school (School 2 ). The class was a required OC I course consisting of 40 first-year students. JTE 2, a Japanese female in her mid-30s, self-evaluated her communicative English level as "not so good." However, based on my 6-month observation, I found her general English abilities to be higher than she thinks and believe she should be considered as above-average. AET 2, a white American female in her mid-20s, had just started her career and life in Japan. She had taught 
high school for 1 year before coming to Japan and was also interested in teaching ESL and getting a TESOL degree in the future.

\section{Qualitative Case Study}

Since this study tries to capture the complex reality of TT relationships, a qualitative case study approach was adopted. I followed the two TT pairs in the JET Program for 6 months, collecting data mainly via individual interviews and classroom observations. Case studies have been advocated in educational research (e.g., Johnson, 1992; Stake, 1998; van Lier, 2005; Yin, 2003) as a powerful means of "understand[ing] the complexity and dynamic nature of the particular entity, and to discover systematic connections among experiences, behaviors, and relevant features of the context" (Johnson, 1992, p. 84). Through studying particular phenomena, case studies emphasize the importance of particularizability, the opposite of generalizability, which is necessary for investigating a single, particular phenomenon on its own terms, in order to avoid simplification of complex social realities (Ramanathan \& Atkinson, 1999; van Lier, 2005). At the same time, case studies provide "comparative information to a wide variety of other cases" (Stake, 1998, p. 198) and assist "readers in the construction of knowledge" (van Lier, 2005, p. 95) regarding the educational phenomenon of interest. A primary purpose of the current research is to stimulate investigation of additional cases in order to understand the dynamics of TT relationships, thereby contributing to the development and improvement of TT relationships in general.

\section{Data Collection Procedures}

A naturalistic study using interviews and observations was conducted from September 2003 to March 2004. To begin with, classes team-taught by the pairs were observed during twice-monthly visits. The total number of hours of class observation was 15 hours and observation data were written up in field notes. Individual interviews with the JTEs and AETs were carried out separately. The interviews included general questions about school life as well as specific ones regarding the events that had taken place in the observed classes. The interviews with AETs were conducted in English and those with JTEs were done in Japanese and then translated into English by the author. The AETs, who had a lighter schedule than the JTEs, were usually able to devote about 40 minutes to 1 hour per interview, while the JTEs, owing to other obligations, could spare only about 20-30 minutes. The total 
interview time for the AETs was about 9 hours, and for the JTEs was about $51 / 2$ hours. The interviews were tape-recorded with the written consent of the interviewees and transcribed for data analysis.

Additional information was collected through interviews with 16 students at the research sites. These interviews were conducted to examine learners' perspectives on TT. The interviews were conducted in Japanese and translated into English by the author.

\section{Results}

Results from the main data-the researcher's observations and interviews with team teachers and the students-are here summarized in two subsections: AETs' characteristics and JTEs' characteristics. At the end, satisfaction and role-sharing in TT, a relevant influential factor on TT relationships, is also reported.

\section{AETs' Characteristics}

The results seem to support the NS-NNS assumption for AETs: AETs were linguistic experts in the target language but cultural novices in the local culture. That is, the AETs' linguistic and sociocultural power as NSs were perceived, but limited exposure and experience made them lacking in the local language/culture skills and they lacked political power owing to their status as assistants.

\section{Linguistically Powerful in the Target Language}

The four teachers interviewed all clearly acknowledged the AETs' linguistic superiority. In particular, AETs' "authentic" English pronunciation was noted by the JTEs. JTE 1 said,

Students probably want to acquire good pronunciation. That's why I take a more passive role in OC courses and let students hear NSs' English as much as possible. Some JTEs are confident in their speaking abilities, but JTEs are not NSs of English.... I never thought that I would teach OC classes alone. If I had to teach them, I would use a tape recorder, which would definitely make classes boring. Things I can do by myself as an NNS in OC classes are quite limited. (Interview, 10/15/03) 
AET 1 supported JTE 1's idea:

Our goal is to speak as much English as possible, and because I am a native speaker, obviously, my English is better and I think maybe it is more clear for students and JTEs .... Well, it's my native language, so I am best suited for it. (Interview, 9/17/03)

Likewise, many students emphasized the importance of learning English from NSs. A student in School 1 illustrated the joy of hearing NSs' authentic English:

We don't have many occasions to encounter foreigners in our daily lives. OC classes are one of the few opportunities for us to be able to hear NSs' real English. When AETs speak English and I understand them, I become so happy. Why? Because the fact that only English is available motivates us to communicate with them. If Japanese is available, we just depend on that too much. (Interview, 3/3/04)

From a teaching perspective, JTE 2 pointed out the AETs' special abilities-quick recognition and correction of learners' mistakes, lenient attitude toward learners' mistakes, exposure to the target language for students-all of which she thinks come from NSs' high level of grammaticality. However, the AETs in this study were not always linguistically accurate. During my class observations, AET 2 wrote "excercise" for "exercise." Although spelling mistakes can be considered trivial, it is notable that AETs, as NSs of English, also made spelling mistakes. In fact, Kan (2002) mentioned that quite a few JTEs reported complaints concerning AETs' misspelling as well as their inability to write grammatically correct sentences. He speculated that the government demand for increasing the numbers of AETs has lowered their quality.

\section{Socio-Culturally Powerful in the Target Language}

Not only NSs' language superiority, but also their high social image attracted Japanese students' attention. Students voiced their admiration toward AETs. One student in School 2 described his special feeling when he received stickers as a prize from AET 2:

AETs' praise is special for us. If we got the same stickers from a JTE, we would feel weird. The fact that foreigners acknowl- 
edge our English makes us happy, because it really shows that we are good at English. Besides, American stickers are cool! (Interview, 2/9/04)

AETs themselves acknowledged students' admiration and attention due to their exotic nature as NSs. Because of this over-admiration, in fact, AET 2 worried about JTEs' envy:

I think that the students tend to like the ALTs, you know, because they are someone different and ... you know, fun and young. ${ }^{4}$ My supervisor told me when I first got here, "Oh, you will be the students' favorite teacher" and all of that. I felt bad for the other JTEs. Well, what do they think? How does that make them feel? Would they resent me because of that? I mean, I haven't experienced any of that here luckily, but I think some of the other ALTs might experience that. (Interview, 1/15/04)

She further mentioned that Japanese students have "a friendly and approachable" image of AETs because of their special position as foreign assistant teachers.

For his part, AET 1 acknowledged the advantages of being a white NS of English. He first mentioned the power of English:

English is not going away. In fact it's just going to spread. I mean, it's an unfortunate reality that Japanese is not going to become a world language .... Those things were in place a couple hundred years ago, I think, for English to do that. Japan obviously is the strongest economy in the world. It's right up there anyway. They want to retain that position. In order to do so, it's English. (Interview, 3/3/04)

He then continued:

Being born a white, male American, it's like hitting the lottery, in a global sense. I could have been born in poverty in India, just those three things: American, male, and Caucasian. That is the easiest path, or at least one of the easiest. Look at my life here in Japan-I am being paid better than I was as a full-time teacher in America. I am being paid 10,000 dollars more and I am only an assistant .... So if you want to be a foreigner in Japan, it is probably best to be a western foreigner. (Interview, 3/3/04) 
According to Kan (2002), AETs' monthly salary of 300,000 yen is even higher than that of JTEs of the same age, which is about 180,000 yen. ${ }^{5}$ Thus, AET 1 referred to their high salaries as evidence of AETs' special treatment. In return for his high salary, AET 1 explained that he had 18 hours of teaching, but few other obligations. In contrast to JTEs, who have a heavy workload, AETs get paid well and have a relatively light workload in spite of their assistant status.

Thus, AETs' powerful socio-cultural image attracted the attention of not only Japanese learners but also administrators, which seemed to result in their special treatment of AETs. Furthermore, it is assumed that in order to satisfy the students' strong desire to communicate with NSs the JTEs took assisting roles in spite of the fact that AETs' official status is only that of an assistant.

\section{Politically Powerless in the Local Culture: AETs as Assistants}

AETs' linguistic and socio-cultural power was not reflected in their political treatment in the educational settings. In other words, despite the fact that AETs were treated as special guests, the results of this study revealed that they still remained politically weak in the education system, since they have the status of "foreign assistants."

In the classroom, AETs were regarded mostly as guests by the students, rather than authoritative teachers who could have a strong effect on students' school work and lives. For example, I observed an incident in which a male student in School 2 cut the TT class and was thereafter scolded by JTE 2. JTE 2 explained,

The boy cut the class and walked around outside, because I assume AET 2 doesn't scold students. AETs are only guests for students, because they never give them grades. Students just regard AETs as someone that speaks "live" English. In contrast, JTEs give them grades and get involved in student discipline in their daily lives, so students see us as some kind of authority. (Interview, 10/27/03)

AET 2 also admitted that students did not behave well without JTEs' presence. AET 1 likewise explained that the lack of AETs' political power results in their leaving student discipline to JTEs.

In fact, the AET's politically weak position was graphically demonstrated during one of my interviews with AET 1 . Two JTEs in the school, who were 
strangers to me, came in the room right after knocking quickly and said in fluent English, "This room is reserved for other purposes from now. Can you evacuate now (meaning 'leave immediately')?" Their fluent but direct request sounded like an order to me and I left the room quickly with AET 1. When I asked the AET later how he felt about the incident:

Some people would say that's rude. I don't see any point in playing on cultural difference. I mean, for me to get upset about it ... I think don't fight it. Unless they're doing something that I consider immoral or dangerous, I have no intention of telling them they shouldn't do things that way... I would expect the same in the reverse situation. I need to listen to them. (Interview, 3/18/04)

He continued:

I am not going to complain, especially in my situation here .. .. Here I am an assistant. That's another thing. That's another reason why I am not frustrated with any of the teaching methods or why I don't complain, because I am an assistant.

Although this incident may have been caused by the JTEs' lack of understanding of English politeness conventions, AET 1 accepted his position as an assistant, or someone of lower status.

\section{Linguistic and Cultural Barriers}

In addition to the fact that the position of "assistants" makes AETs powerless (Voci-Reed, 1994), the results of this study reveal that the AETs are already powerless in Japanese schools due to linguistic and cultural barriers, regardless of their political status.

The language barrier caused by not being conversant in Japanese affected the AETs' teaching significantly, causing frequent confusion in class. For example, although the AETs put great effort into making themselves understood in English by using easy words, expressions, and gestures in the classroom, even simple instructions for activities and games were often not understood well by students. Thus, when AET 1 told the class during one of my observations "After you answer, choose the next person," the students didn't understand. On another occasion, AET 1 asked "Who is the little girl?" in order to find a volunteer to read the part of the little girl in a textbook conversation, but his question confused students, who tried to find the name of 
the girl, which was not known.

Although AETs in this study believed that Japanese language skills could help close the cultural and linguistic gap between their students and themselves, AET 1 asserted that mastering the Japanese language requires enormous effort because of its complexity:

I never really intended, to be honest with you, to learn Japanese all that intricately .... Because it is hard .... It was a silly idea, but I was thinking that learning Japanese would be like learning Spanish .... I mean it is kind of shameful for me to admit this but I really don't study Japanese all that hard .... I realize that I am leaving and I realize that I can't master it and [all I want to do is] to really just have fun with it. (Interview, $12 / 17 / 03)$

As a consequence, AET 1 recognized the importance of JTEs' role in transmitting information to students precisely and effectively:

I really need a JTE, especially in a writing class, where it is really helpful for a detailed explanation. But even in oral communication, it kind of helps, you know. Maybe I am talking too fast or maybe I am using vocabulary that they don't understand . .. and I mean a lot of people say, that it's best to have just a pure English instruction. I kind of disagree because if you are trying to explain something, just the one push in Japanese by the teacher can lead to so much more understanding on their part. (Interview, 10/15/03)

As for the cultural barrier, both AETs in this study encountered different values from the local society concerning classroom and societal cultures. For example, they revealed their inability to understand their students' silence and passive attitude toward learning. AET 2 said,

It seems like, especially with Japanese students, because they are so shy and I can basically count on them not volunteering even though I ask for a volunteer. I would like to try just in case a student will raise their hand, but I expect to have to call on the students because I know they are not going to volunteer... . I mean, in America, you know, any student is going to get shy or embarrassed by standing in front of their peers, but here it seems a little more extreme. (Interview, 10/6/03) 
AET 1 also described difficulties in dealing with silent students:

I don't like to sit there in dead silence and wait for an answer that is not going to come .... Yeah, [students should try to answer] either through a gesture or an expression or a sound. But yeah, that student there, he wasn't moving ... I knew he was awake. (Interview, 10/15/03)

AET 1 described his changing feelings in this regard:

But I've gotten used to it. I've gotten to a point where, in the past, answers like, "I don't know" or "No" were unacceptable answers. So, I would press and, [sometimes] just to the chagrin of the student who was being focused on. You see him writhing like, "Leave me alone," so usually I'll back off. (Interview, $2 / 18 / 04)$

He further explained,

But, sometimes I feel bad, though, I don't know, maybe if you don't let them answer and move on, well, maybe they were going to answer and somehow they feel like they failed. And even now when that happens sometimes, I'll try to come back to that student later with an easier question. I just get a sense of crushing defeat from that student or something. I'd just like to let them say something, let them think about something to have some small success. (Interview, 10/15/03)

Thus, the AETs still had difficulties dealing with Japanese classroom culture although they knew that Japanese group norms and face issues contributed to the students' passive learning attitude. In sum, the AETs were not only politically but also culturally powerless in relation to the local culture.

\section{JTEs' Characteristics}

The results also seem to support the NS-NNS assumption for JTEs: JTEs were linguistic novices in the target language but cultural and occupational experts in the local culture. The JTEs in this study revealed lack of confidence in their English abilities and their belief in the native speaker fallacy. However, the JTEs' important roles as linguistic, cultural, and psychological mediators to fill the gaps between Japanese students and AETs were acknowledged by the teachers and students. 


\section{Culturally Powerful in the Local Culture: \\ JTEs as Language/Cultural/Psychological Mediators}

JTEs' role as language and cultural mediators was pointed out by the team teachers and students in this study. AET 1 and AET 2 readily admitted that JTEs' language support was indispensable for both the students and the AETs themselves to avoid confusion. AET 2 referred, in particular, to the importance of making complicated directions or difficult explanations more clear. AET 1 also emphasized JTEs' translating role for in-depth understanding and precise explanation. The JTEs themselves acknowledged their role as language and cultural mediators. JTE 2 stated that her role was to prepare a comfortable learning environment by being a gap filler between AETs and Japanese students. JTE 1 also described his role as a language mediator who is empathetic to students struggling with foreign language learning:

For instance, an easy question becomes difficult for Japanese students because of NSs' authentic pronunciation and intonation. They are not familiar with them. Also, they can be careless and miss NSs' utterances when their concentration breaks down. Their English level is still not so high, so even if they don't understand, they don't know how to say that in English. Learning a foreign language is stressful. (Interview, 3/3/04)

The JTEs' mediating roles were appreciated by students as well. One student in School 1 said,

We learned that looking away from AETs is an impolite behavior from JTE 1, so I avoid doing so even when I don't know how to answer. It's important to know this, so AETs won't misunderstand us. (Interview, 3/3/04)

Another student in School 2 asserted that JTEs provided psychological relief:

I can speak with AET 2 without worrying because we have JTE 2. She fills cultural gaps between us and gives us psychological relief. You know, JTEs help us when troubles arise. For example, AETs sometimes misunderstand Japanese students' silence. We may be silent because we are extremely nervous or embarrassed. It's hard for AETs to understand that. JTEs understand Japanese students' feelings better. (Interview, 2/9/04) 
In fact, the JTEs' better grasp of Japanese students' lives and feelings were observed during my class observations. For example, JTE 1 paid special attention to students' "face issues" in class. When AET 1 casually asked one student how he liked an activity which involved translating English cartoons into Japanese, the student answered, "So-so." Presumably, AET 1 thought that the student was able to translate the cartoons and asked him to explain it in Japanese for the class, but the student couldn't say anything. The class was uncomfortably silent for a moment. Then JTE1 helped the student translate the cartoon without embarrassing him, by inferring from his facial expression that he actually hadn't understood the cartoon.

In addition, understanding Japanese humor seemed to help create a bond with students. JTE 1 showed his sense of humor with his Japanese students. One day he brought a toy ear to surprise the students. He covered his ear with the toy ear and said "What did you say?" in English. The students burst into laughter.

In particular, JTEs' better grasp of students' vocabulary was acknowledged as one of the major advantages of JTEs. JTE 1 said,

JTEs know what words are taught by now, so we can easily rephrase difficult words when students don't understand. Moreover, it is a trivial thing, but we know that classes after P.E., for example, should be conducted at a slower pace because students are usually tired after exercising. (Interview, $9 / 17 / 03)$

Thus, the JTEs' knowledge of the students' lives as well as the local language and culture seemed to create their image as psychological mediators and trust from the students.

\section{Linguistically Powerless in the Target Language}

In spite of the numerous advantages, the JTEs in this study pointed out AETs' language superiority. JTE 2 revealed her lack of confidence in her English language abilities. Even JTE 1, a fluent English speaker, confessed that he had been scared of TT when he started his teaching career. He said he had a fear of revealing his inability in understanding AETs in front of students and the AETs themselves, but TT became less of a psychological burden after he gained confidence in his communicative English skills. Even now, he makes efforts to maintain his English skills by talking with AETs, as well as reading about 50 English paperbacks and watching about 70 English movies a year. 
JTE 1 further revealed the realities of some JTEs' poor English abilities as follows:

As a matter of fact, there are still many JTEs who don't want to speak to AETs due to their poor communicative abilities. Actually, I watched a JTE's open class the other day, but to be honest, it was miserable. I know it's impolite to say this, but the JTE's English was terrible. (Interview, 3/3/04)

Moreover, JTE 1 referred to the current emphasis on CLT, which has put the pressure on JTEs to avoid the use of Japanese in class. He explained,

I have a growing sense of crisis about my status as an NNS in CLT-emphasized policy. Nowadays, English has been introduced in elementary schools. If students acquire speaking and listening abilities in the earlier stages, we will need to teach some kind of content in English. To do that, more NSs will be hired and JTEs who cannot do that may lose their jobs. At this moment, there are still many students who cannot understand English without Japanese explanation, so JTEs are necessary. But in the future, people will recognize the necessity of NSs' authentic English and may criticize JTEs' poor English communicative abilities. Maybe JTEs with near-native abilities will survive, but more training should be given to present JTEs. Otherwise, JTEs will have no choice but to specialize in teaching reading and grammar only. (Interview, 3/3/04)

In sum, it is expected that JTEs' English language deficiency in general results in a lack of confidence, which has led to a situation wherein JTEs were not the total power dominators in spite of their designated political power as teachers, not assistants.

\section{JTEs' "Native Speaker Fallacy"}

The JTEs' lack of confidence in English language abilities seems to result in their belief in the native speaker fallacy. For example, JTE 2 confessed her recognition of NSs, especially British and Americans, as ideal teachers of English:

I know it is a prejudice, but if I were to have formal English education myself, to be honest, I would prefer NSs as my teach- 
ers. For example, if I were to learn English myself and pay for a language school such as AEON or NOVA, I would choose American or British teachers ... because they speak correct English .. .. Of course I know Indian English and Singaporean English are both World Englishes. I have stayed with a Singaporean family in the home-stay program in Canada and it was good training for me to try my English. But if I learn English from them, I cannot help questioning their accent and grammaticality. (Interview, 3/22/04)

JTE 2 explained that students' admiration of NSs led her to take an assistant role in TT settings:

Our students really look forward to classes with AETs. There are few occasions for them to have them. We only have them once a week, so I hesitate to become the main teacher. I don't want to disturb AETs' classes, so I take the assisting role. I also take the role of student disciplinarian so that AETs can concentrate on teaching and students have a good image of them. Hopefully, this helps to create a fun class atmosphere. (Interview, 11/10/03)

Actually, in the classes taught by both Team 1 and Team 2, the AETs were the main teachers, standing in the center of the classroom, while the JTEs including JTE 1, who has high English communicative skills, took the roles of assisting, translating, disciplining students, and engaging in off-stage chores such as writing on the blackboard and distributing handouts, while standing to the side. JTE 1 expressed a similar opinion:

Although AET 1 is an assistant and I am supposed to stand in the center as the main teacher, I think it's more natural to position him as the main teacher because we are teaching an English conversation course. Our students also prefer it that way. (Interview, 10/15/03)

Later, JTE 1 clarified his view of English and the NSs as follows:

It is a fact that English is an international language and we Japanese, speakers of a minor language, are learning the international language .... Besides, if NSs were not the lead teachers in TT, inviting them from overseas would be meaningless, anyway. (Interview, 3/10/04) 
Thus, the JTEs' belief in the native speaker fallacy influenced their decisions in responsibility/role-sharing in TT settings. To be specific, their belief in the native speaker fallacy seems to be shared with the students and possibly the local people in the society, which might have legitimatized the JTEs' peripheral participation in TT and protected their professional pride as English teachers.

\section{Satisfaction and Role-Sharing in TT}

The pairs were asked to give an evaluation of their own performance based on a 100-point scale. The impressionistic question did not have the purpose of rating TT performances statistically. Such measures cannot be used as valid statistics for various reasons, including individual and cultural differences in interpretation of evaluation scales. ${ }^{6}$ However, investigating specific reasons for their self-evaluations may reveal their honest feelings about their TT relationships.

AET 1 evaluated Team 1's TT performance as earning 90 points out of 100 , saying he had subtracted 10 points for lack of preparation or possible future improvement; AET 2 gave a higher score of 95 points to her team's performance. Presumably, these relatively high scores were because the AET had full autonomy and was the main teacher in class. AET 1 justified the reason for taking the leadership in their TT classes:

JTE 1 is an ichinensei (1st year) homeroom teacher and throughout the week he teaches 16 classes. So they see me once a week. They see him once a day .... I mean, of their English instruction, I am a very small part of it. (Interview, 1/17/04)

In fact, JTE 1 admitted that he defers to AET 1, because he can enjoy full autonomy in other courses where he teaches alone. He further revealed his true feelings about TT by giving 75 points to Team 1's performance:

To be honest, I don't feel like spending time and effort to prepare for only one or two TT classes. OC classes are not as important as classes of grammar and reading. University entrance examinations still emphasize grammar and reading, so OC courses are not main subjects in our school. (Interview, $2 / 18 / 04)$

JTE 2, who gave 60 points to Team 2's performance, regretted her passive involvement in TT: 
Our students seemed to enjoy our classes because they had many activities and games, which was meaningful and good for the 1st-year students in terms of experiencing an NS's class. But I don't know how much they improved their English. I should have at least gotten involved actively in setting goals and objectives of the course and planning teaching procedures.

Thus, in contrast to the AETs, the JTEs gave lower scores to their TT and did not show full satisfaction in their teaching. Presumably, the JTEs' passive involvement in TT may have led to their lower satisfaction in their TT performance.

\section{Discussion}

The results of this study show that while JTEs were linguistic novices, they were cultural experts, and while AETs were linguistic experts, they were cultural novices in this EFL setting. To be more specific, the AETs in this study faced different cultural values as cultural minorities in the classroom due to their lack of cultural power. AET 1 showed low motivation to learn Japanese and AET 2 was a total novice in terms of teaching and living in Japan.

Regarding language power, however, even JTE 1, who had high English communicative abilities, deferred to AET 1, which created a power balance: JTE 1 as the cultural expert and AET 1 as a linguistic expert. However, the power structure did not result in equal role-sharing but led to JTE 1's more passive involvement. This is perhaps why JTE 1 expressed dissatisfaction in their TT performance. Thus, AET 1, as a target language expert lacking political, linguistic, and cultural power in the local culture, became the major teacher in the OC class, which may imply that target-language power could be more significant than any other power in terms of power sharing in the TT setting.

In Team 2, both teachers lacked one of two forms of power-either language or cultural power. JTE 2 clearly revealed her lack of confidence in her communicative English abilities. In other words, while JTE 2 was a linguistic novice, AET 2 was a cultural and occupational novice. However, JTE 2 invariably yielded the floor to AET 2, a 1st-year AET and a total novice in the Japanese school, due to her lack of confidence in her English abilities and her belief in the native speaker fallacy, which may have led to her relative dissatisfaction in their TT performance.

The JTEs' largely peripheral participation was thus deeply influenced by language-power inequality, which seems to be supported by the belief in the 
native speaker fallacy at the educational, societal, and individual levels. In fact, as Butler (2005) pointed out, it can be said that the belief in the native speaker fallacy is built into the JET Program itself, based on the following two facts: (1) nearly 96\% of AETs are from "core English-speaking countries" (CLAIR, 2003); and (2) they are, by and large, recent university graduates with little or no teaching experience (Tajino \& Tajino, 2000). Thus, it is clear that the Japanese government regards NSs from major English-speaking countries, who are, in most cases, not even teachers at all, as qualified and suitable to be assistant English teachers based on their perceived inherent superiority as NSs. Thus, with the initiative of the central government, an influential element in the society, the belief in the native speaker fallacy has become deeply embedded in the EFL profession in Japan.

\section{Concluding Remarks}

This study revealed that the particular TT relationships observed turned out to be deeply involved with social complexities of power relations between NSs and NNSs that seem to prominently concern English language proficiency. First of all, it is strongly recommended that JTEs be provided opportunities to establish self-confidence in their language abilities. Surely, the JET Program has contributed to raising JTEs' English communicative abilities through on-the-job training by working with an NS regularly in and outside the classroom. According to JET Programme: Looking Towards the Future After 15 Years (CLAIR, 2002), more than 95\% of JTEs in the study acknowledged AETs' positive effect on their English abilities. In addition, the central and local governments have recently offered JTEs seminars to improve their teaching and communicative English abilities. However, in order to be confident and comfortable enough to work with NSs, extensive training in the daily use of English is necessary. Studying abroad is also an important option, because it can provide JTEs the additional advantage of cross-cultural experience as well as the experience of being in a linguistic and cultural minority. According to a MEXT action plan entitled "Eigo-ga tsukaeru nihonjin no ikusei notameno koudou keikaku" ["Regarding the Establishment of an Action Plan to Cultivate Japanese With English Abilities"] (MEXT, 2003), the National Center for Teacher Development, a government body under MEXT, provided overseas training opportunities for 15 JTEs for 12 months each and 85 JTEs for 6 months each in 2003. In total, then, only 100 JTEs a year have been given the opportunity for intensive overseas training, an enormously small number compared to the nearly 6,000 AETs who have been hired annually through the JET Program. It can also be 
speculated that the lack of extensive cross-cultural or overseas experience of JTEs might contribute to cross-cultural misunderstandings between JTEs and AETs.

Another important issue is to lessen or at least call into question the power of the native speaker fallacy in the minds of both AETs and JTEs. First, JTEs as well as AETs should recognize the significance of NNS teachers in EFL settings, who play the crucial role of filling cultural and linguistic gaps between students and NSs based on close familiarity with the learners and experience with teaching and learning skills. Although not investigated in this study, learning/teaching about World Englishes may also lessen students' and teachers' over-admiration of NSs. Through awareness of varieties of English in the world, students may be able to establish appropriate goals and learner identity. In addition, we can consider creating an environment based on Kubota's (1999) critical multiculturalism in Japanese educational settings with various types of EFL teachers. For example, through hiring NNS AETs from different parts of the world and exposing Japanese learners to a variety of Englishes and cultures, learners would be enabled to explore cultural differences without uncritically linking the target language to some exotic culture and get a better sense of and appreciation for World Englishes.

In conclusion, we should carefully consider power issues of English language teaching and learning. Through the insightful divergences such consideration may yield, it is hoped that the Japanese people's belief in the native speaker fallacy will be subject to change.

\section{Acknowledgements}

I would like to thank the participants of this study for their cooperation and Dr. Dwight Atkinson for his valuable comments. I also appreciate the useful suggestions made by the anonymous reviewers.

Kyoko Miyazato, Ed.D, is an associate professor of EFL and TESOL at Hakuoh University in Oyama City, Tochigi. Her research interests include team teaching, NS-NNS issues, and intercultural communication.

\section{References}

Browne, C., \& Evans, B. (1994). The ALT as cultural informant: A catalyst for developing students' communicative competence. In M. Wada \& A. Cominos (Eds.), Studies in team teaching (pp. 17-28). Tokyo: Kenkyusha.

Brumby, S., \& Wada, M. (1990). Team teaching. London: Longman. 
Butler, Y. G. (2005). Nihon-no shoggakou eigo o kangaeru-Asia no shiten karano kensho to teigen [English language education in Japanese elementary schools: Analyses and suggestions based on East Asian perspectives]. Tokyo: Sanseido.

CLAIR (The Council of Local Authorities for International Relations). (1992, May). CLAIR question and answer time. Session conducted at the JET program(me) Renewers' Conference, Kobe.

CLAIR. (2000). Resource materials \& teaching handbook 2000. Tokyo: CLAIR.

CLAIR. (2002). JET Programme: Looking forward to the future after 15 years. Tokyo: CLAIR.

CLAIR. (2003). The JET Programme 2003-2004. Tokyo: CLAIR.

Deci, E. L., \& Ryan, R. M. (1985). Intrinsic motivation and self-determination in human behavior. New York: Plenum.

Ellis, G. (1996). How culturally appropriate is the communicative approach? ELT Journal, 50, 213-228.

Ellis, R. (1993). The structural syllabus and second language acquisition. TESOL Quarterly, 27, 91-113.

Fujikake, S. (1996). JET Program to chiiki-shakai [JET Program and its community]. Modern English Teaching, 9, 25-27.

Gorsuch, G. J. (1999). Exploring the relationship between educational policy and instruction in Japanese high school EFL classrooms. Unpublished doctoral dissertation. Temple University.

Gorsuch, G. J. (2002). Assistant foreign language teachers in Japanese high schools: Focus on the hosting of Japanese teachers. JALT Journal, 24(1), 5-32.

Holliday, A. (1994). Appropriate methodology and social context. Cambridge: Cambridge University Press.

Iwamoto, K. (1999). Atarashii 'communication' no jugyo niokeru kyodo-jyugyo [Team teaching in new 'communication' courses]. The English Teachers' Magazine, 3, 3436.

Johnson, D. M. (1992). Approaches to research in second language learning. White Plains, NY: Longman.

Kamhi-Stein, L. D. (1999). Preparing non-native professionals in TESOL: Implications for teacher education programs. In G. Braine (Ed.), Non-native educators in English language teaching (pp. 145-158). Mahwah, NJ: Lawrence Erlbaum Associates.

Kan, M. (2002). ALT-ga fuerunowa iikeredo-Koeni dashite yondewa ikenai ALT mondai [Increasing the number of ALTs is good, but...-ALTs' problems to be discussed secretly]. The English Teachers' Magazine, 11, 16-17. 
Kitayama, S., Markus, H., Matsumoto, H., \& Norasakkunkit, V. (1997). Individual and collective processes in the construction of the self. Journal of Personality and Social Psychology, 72, 1245-1267.

Kubota, R. (1998). Ideologies of English in Japan. World Englishes, 17(3), 295-306.

Kubota, R. (1999). Japanese culture constructed by discourses: Implications for applied linguistics research and ELT. TESOL Quarterly, 33(1), 9-36.

Kumabe, N. (1996). ALT donyu ga motarashita mono [What ALTs have brought about]. Modern English Teaching, 9, 13.

Lincicome, M. (1993). Nationalism, internationalization, and the dilemma of educational reform in Japan. Comparative Education Review, 37(2), 123-151.

Liu, D. (1999). Training non-native TESOL students: Challenges for TESOL teacher education in the West. In G. Braine (Ed.), Non-native educators in English language teaching (pp. 197-210). Mahwah, NJ: Lawrence Erlbaum Associates.

Mahoney, S. (2004). Role controversy among team teachers in the JET Programme. JALT Journal, 26(2), 223-244.

McConnell, D. (2000). Importing diversity: Inside Japan's JET Program. Berkeley: University of California Press.

Ministry of Education, Culture, Sports, Science and Technology (MEXT). (2003). "Eigo-ga tsukaeru nihon-jin" no ikusei notameno koudou keikaku. [Regarding the establishment of an action plan to cultivate "Japanese with English Abilities"]. Tokyo: MEXT.

Miyazato, K. (2003). Japanese EFL learners' anxiety in native speaker teachers' classes. JALT Conference '02 Proceedings, 1-8. Tokyo: JALT.

Murai, G. (2004). Using checklists: A way of reducing surprises in team-taught classes. The Language Teacher, 28(11), 35-40.

Ogawa, H. (1998). Kenshu toshiteno JET Program [JET Program as teacher training]. The English Teachers' Magazine, 1, 20-22.

Phillipson, R. (1992). Linguistic imperialism. Oxford: Oxford University Press.

Ramanathan, V., \& Atkinson, D. (1999). Ethnographic approaches and methods in L2 writing research: A critical guide and review. Applied Linguistics, 20(1), 44-70.

Samimy, K. K., \& Kobayashi, C. (2004). Toward the development of intercultural communicative competence: Theoretical and pedagogical implications for Japanese English teachers. JALT Journal, 26(2), 245-261. 
Sensei ga chikara busoku ja... Kouritsu-chu "Eigo-de jyugyo" wa 4\% dake-Monkasho mokuhyo ni tooku [Deficiency of English language abilities of English teachersFar from MEXT's goal, only 4\% of public junior high school teachers conducted English-only classes]. (2005, July 18). Yomiuri Shimbun, p. 31.

Stake, R. E. (1998). Case studies. In Denzin, N. K., \& Lincoln, Y. S. (Eds.), Strategies of qualitative inquiry (pp. 86-109). Thousand Oaks, CA: Sage.

Sugino. T. (2002) Asia English to gakusei-no ishiki [Asian Englishes and its roles in English education]. Studies in Humanities and Social Sciences of the National Defense Academy, 85, 11-31.

Suzuki, T. (1999). Nihonjin wa naze eigo ga dekinaika [Why are Japanese poor at English?]. Tokyo: Iwanami Shoten.

Tajino, A., \& Tajino, Y. (2000). Native and non-native: What can they offer? Lessons from team-teaching in Japan. ELT Journal, 54, 3-11.

Tajino, A., \& Walker, L. (1998). Perspectives on team teaching by students and teachers: Exploring foundations for team learning. Language, Culture, and Curriculum, 11(1), 113-131.

Takada, T. (2000). The social status of L1 Japanese EFL teachers. TESOL Matters, 10 (3), 23.

Tsuda, Y. (1997). The hegemony of English vs. the ecology of language: Building equality in international communication. World Englishes 2000 (pp. 21-31). Honolulu: University of Hawaii Press.

van Lier, L. (2005). Case study. In E. Hinkel (Ed.), Handbook of research in second languge teaching and learning (pp. 195-208). Mahwah, NJ: Lawrence Erlbaum Associates.

Voci-Reed, E. (1994). Stress factors in the team teaching relationship. In M. Wada \& A. Cominos (Eds.), Studies in team teaching (pp. 61-71). Tokyo: Kenkyusha.

Wada, M. (1994). Team teaching and the revised course of study. In M. Wada \& A. Cominos (Eds.), Studies in team teaching (pp. 7-16). Tokyo: Kenkyusha.

Wada, M. (1996). AET donyu to nihon-no eigo kyoiku [Introduction of AETs and English Education in Japan]. Modern English Teaching, 9, 6-8.

Wada, M., \& Cominos, A. (1994). Editors' introduction: Language policy and the JET Program. In M. Wada \& A. Cominos (Eds.), Studies in team teaching (pp. 1-6). Tokyo: Kenkyusha.

Yin, R. K. (2003). Applications of case study research (2nd ed.). Thousand Oaks, CA: Sage. 


\section{Endnotes}

1. The maximum length of employment for AETs used to be 3 years, but has been extended to 5 years under the condition that they are well qualified in regard to their contribution, experience, and motivation.

2. Phillipson (1992) criticized the uncritical belief in the NSs' superiority and called this belief the native speaker fallacy-the idea that NSs of English are per se the best teachers of the language.

3. A TOEIC score 730 , or TOEFL score 550 , is supposed to be the minimum English proficiency needed for international students to enter a university in English-speaking countries. According to a MEXT action plan "Eigo-ga tsukaeru nihonjin no ikusei notameno koudou keikaku" ["Regarding the Establishment of an Action Plan to Cultivate Japanese with English Abilities"] (MEXT, 2003), the government expects JTEs in secondary schools to have the score or above.

4. Assistant language teachers (ALTs) include not only AETs but also assistant teachers of other foreign languages such as French and Chinese. However, in common parlance, "ALT" is used interchangeably with "AET."

5. The difference in annual salary between young JTEs and AETs should be marginal when JTEs' bonuses are included.

6. For example, Japanese tend to emphasize self-criticism rather than selfenhancement to fit into the group norm (Kitayama, et al., 1997), and, therefore, they may give lower points in evaluating their TT satisfaction than Americans. It is also expected that JTEs in this study feel reluctant to give a high score on their own performance out of modesty or politeness in front of me, a Japanese university EFL teacher. 